\title{
Effect of Training on the Properties of Isolated Skeletal Muscles
}

In a recent investigation into the separate effects on intensity and duration of training routines (running on an endless belt) on the size of muscle fibres, it was demonstrated that, albino mice trained for $15 \mathrm{~min} /$ day at $0.83 \mathrm{ft} / \mathrm{sec}$ for 3 weeks, showed an increase in mean fibre cross-sectional area of $49.0 \%$ (WALKER $^{1}$ ). The present report relates this change in fibre size to changes in the mechanical properties of the isolated muscles.

After training was complete the biceps brachii and the tibialis anterior were isolated. The right fore and hind limbs were amputated close to their respective limb girdles and thread was attached to the proximal tendon in the case of the biceps brachii and the distal tendon in the case of the tibialis anterior. These tendons were subsequently severed and the preparation pinned to a cork board through the bone left attached to the remaining tendon, and immersed in a constant temperature $\left(35^{\circ} \mathrm{C}\right)$ bath containing $150 \mathrm{ml}$ mammalian Ringer. The solution was aerated and gently stirred by bubbling a mixture of oxygen $(95 \%)$ and carbon dioxide $(5 \%)$ through it. One platinum electrode was wound around the muscle and the other dipped into the Ringer's solution. Iso-metric measurements of muscle strength were recorded on a Physiograph ( $\mathrm{E}$ and $\mathrm{M}$ Instrument Company). The load-

Mechanical properties of isolated muscle preparations from control and trained mice

\begin{tabular}{|c|c|c|c|}
\hline & & $\begin{array}{l}\text { Biceps } \\
\text { brachii }\end{array}$ & $\begin{array}{l}\text { Tibialis } \\
\text { anterior }\end{array}$ \\
\hline Twitch tension & $\begin{array}{l}\text { Control } \\
\text { Exercised }\end{array}$ & $\begin{array}{l}1112.4 \pm 70.7^{\mathrm{a}} \\
1836.5 \pm 195.0^{\circ}\end{array}$ & $\begin{array}{l}448.7 \pm 40.3^{\mathrm{b}} \\
785.5 \pm 72.6^{\mathrm{b}}\end{array}$ \\
\hline Tetanus tension & $\begin{array}{l}\text { Control } \\
\text { Exercised }\end{array}$ & $\begin{array}{l}1845.0 \pm 121.7^{\mathrm{b}} \\
2870.5 \pm 141.3^{\mathrm{b}}\end{array}$ & $\begin{array}{l}540.6 \pm 54.8^{\mathrm{b}} \\
969.8 \pm 69.6^{\mathrm{b}}\end{array}$ \\
\hline $\begin{array}{l}\text { Half-fatigue } \\
\text { time for } \\
\text { tetanus (sec) }\end{array}$ & $\begin{array}{l}\text { Control } \\
\text { Exercised }\end{array}$ & $\begin{array}{l}5.83 \pm 0.74^{a} \\
8.94 \pm 0.34^{a}\end{array}$ & $\begin{array}{l}6.00 \pm 0.65^{\circ} \\
7.73 \pm 0.80^{\circ}\end{array}$ \\
\hline
\end{tabular}

Mechanical properties of isolated muscle preparations from trained and control mice. Each figure represents the mean of 10 muscle preparations. Tensions are expressed as $\mathrm{g} / \mathrm{g}$ wet weight of the muscle. S.E., Standard error. " Significant at $1 \%$ level. ${ }^{\circ}$ Significant at $0.1 \%$ level. N Not significant. ing tension in every case for both muscles was $3.8 \mathrm{~g}$. The characteristics of maximal single twitches were measured following a single pulse of 50 volts lasting $2 \mathrm{msec}$. The muscle was put into tetanus using one hundred $50 \mathrm{~V}$ pulses/sec. These values were found to give the maximal response. The trained muscle preparations were compared with preparations from untrained mice of the same initial body weight $(35 \mathrm{~g})$.

The results in the Table show significantly increased tensions and prolonged fatigue times for the 2 muscles following training. No significant differences were found in contraction times, relaxation times or latent periods following twitch stimulation and the results are not presented here. However, the increase in tension developed by tetanus stimulation (55.6\% for the biceps brachii and $79.4 \%$ for the tibialis anterior) is not proportional to the increase in fibre cross-sectional area $(49.0 \%)$.

It is suggested that this disproportionate increase in strength is associated with the thickening of myofibrils recently described by MOLBERT and JIJIMA ${ }^{2}$ and GoLDSPINK $^{3}$. Presumably this thickening of the myofibrils would not influence the cross-sectional area of the fibres to the same extent as a proportional increase in their number ${ }^{4}$.

Zusammenfassung. Weisse Mäuse wurden 3 Wochen auf einem endlosen Band trainiert. Ihre Skelettmuskeln zeigten in vitro erhöhte isometrische Spannung und geringere Ermüdung bei tetanischer Reizung. Die Zunahme an Faserquerschnittsfläche dieser Muskeln war relativ geringer als die Zunahme der Kraftentwicklung. Es wird angenommen, dass diese Disproportionalität als Resultat einer Verdickung der Myofibrillen zu deuten ist.

M. G. WALKER

\section{Department of Zoology, Trinity College}

Dublin (Ireland), 20. November 1967.

1 M. G. Walker, Comp. Biochem. Physiol. 19, 791 (1966).

2 G. Goldspink, Am. J. Physiol. 209, 100 (1965).

3 E. Molbert. and J. Jijima, Verh. dt. path. Ges. 42, 349 (1959).

4 I wish to thank Prof. J. N. R. Grainger for supervision and Dr. F. R. HARDEN Jones for comment. The study was supported by the U.S. Army (Contract No. DA-91-591-EUC-3076).

\section{The Activity of Neurons in the Lateral Geniculate Body During Wakefulness and Natural Sleep}

It is well known that the activity. of thalamic and cortical neurons shows marked changes in the transition from wakefulness to sleep ${ }^{\mathbf{1 - 1 6}}$. Much of the previous research on this subject has been conducted in anesthetized or restrained animals and has dealt with the 'slow-wave' phase of sleep. The purposes of the investigations reported here have been: (1) to study quantitatively the changes which occur in thalamic neuronal activity in unrestrained, unanesthetized animals; (2) to include in the study the phase of 'low voltage-fast wave' sleep ${ }^{12,13,14,16}$; (3) to determine the extent of the neuronal territory within which the changes in neuronal activity occur; (4) to develop a method of implantation of microelectrodes which is simple and does not involve the use of metallic cannulae which frequently cause injury to brain tissue and shorting of the connecting leads.
Materials and methods. Microelectrodes made of platinum-iridium wire, sharpened electrolitically to diameters of from 1-5 $\mu$ and insulated with glass ${ }^{17}$, were implanted in the brain of 7 cats, under barbiturate anesthesia. After implantation the animals were maintained for periods of from 2-8 weeks, and the neuronal activity was studied in the unanesthetized, unrestrained state, in wakefulness or in sleep.

The data analyzed statistically and presented in this report are from 2 of these animals. The first animal was implanted with 3 microelectrodes in the lateral geniculate body, and recordings from 2 of the microelectrodes (400 micra apart) were taken 1 month after implantation. The second cat was implanted with 1 microelectrode in the lateral geniculate and recordings were obtained 15 days after implantation. Quantitative studies were performed 